\title{
Index of Injury Compared to Tissue Ionic Conductance for Calculating Freeze Damage of Cabbage Tissues
}

\author{
Reeser C. Manley ${ }^{1}$ and Rita L. Hummel ${ }^{2}$ \\ Department of Horticulture and Landscape Architecture, Washington State University Puyallup Research \\ and Extension Center, Puyallup, WA 98371
}

Additional index words. cold hardiness, $\mathrm{TK}_{50}$, triphenyl tetrazolium chloride, Brassica oleracea Capitata group, stem pith, lamina, petiole

\begin{abstract}
The index of injury $\left(\mathrm{I}_{t}\right)$ and tissue ionic conductance $\left(\mathrm{g}_{\mathrm{Ti}}\right)$ formulas for analyzing electrolyte leakage data from freeze-stressed tissues of cabbage (Brassica oleracea L. Capitata group) were compared. The two formulas produced similar results in calculating the relative freezing responses of stem pith, lamina, and petiole tissues. Disagreement occurred only with lamina tissues when the magnitude of ion leakage was low. Vital staining of pith and petiole tissues with triphenyl tetrazolium chloride indicated that the tissue $\mathbf{T K}_{50}$ (the temperature resulting in $50 \%$ injury), derived from $I_{t}$ data, was a reliable indicator of the freeze-killing point. These results support the use of the simpler $I_{t}$ method for analyzing electrolyte leakage data in studies of cabbage freezing tolerance.
\end{abstract}

Measurement of electrolyte leakage from freeze-damaged plant tissues is an established procedure for determining freezing tolerance (Dexter et al., 1930, 1932; Flint et al., 1967; Murray et al., 1989; Stergios and Howell, 1973; Stuart, 1939). Since its inception (Dexter et al., 1930, 1932), the procedure has undergone many modifications. The use of simple specific conductivity (EC) measurements proved unreliable when samples varied in total electrolyte levels. This problem was addressed by Stuart (1939), who expressed specific conductivity as a percentage of total electrolytes released from the sample by heat killing.

Flint et al. (1967) introduced the expression of freezing damage on an index of injury scale from 0 (nonfrozen tissue) to 100 (heatkilled tissue), using the following formula:

$$
\mathrm{I}_{\mathrm{t}}=100\left(\mathrm{R}_{\mathrm{t}}-\mathrm{R}_{\mathrm{o}}\right) /\left(1-\mathrm{R}_{\mathrm{o}}\right) ; \mathrm{R}_{\mathrm{t}}=\mathrm{L}_{\mathrm{r}} / \mathrm{L}_{\mathrm{k}} ; \mathrm{R}_{\mathrm{o}}=\mathrm{L}_{\mathrm{o}} / \mathrm{L}_{\mathrm{d}}
$$

where $I_{t} i$ the index of injury (or percent injury), $R_{t}$ and $R_{o}$ are the relative conductivities for treatment and control, respectively, $\mathrm{L}_{\mathrm{t}}$ is the specific conductivity of leachate from sample frozen at temperature $t, L_{k}$ is the specific conductivity of leachate from sample frozen at temperature $t$ and then heat-killed, $L_{o}$ is the specific conductivity of leachate from nonfrozen control samples, and $\mathrm{L}_{\mathrm{d}}$ is the specific conductivity of leachate from nonfrozen heat-killed samples (Flint et al., 1967). This formula, which assumes that ion leakage behavior of control tissue is linearly related to the behavior of treated tissue, presumably compensates for treatment variability in electrolyte leakage from nonfrozen control samples. Some researchers plot the $I_{t}$ as a function of temperature and interpolate to obtain the temperature at which 50\% leakage occurred, termed the $\mathrm{TK}_{50}$ (Piotrowska and Kacperska, 1990) or $\mathrm{LT}_{50}$ (Kacperska and Szaniawski, 1993), values considered arbitrarily to be the freeze-killing temperature.

The reliability of $I_{t}$ as a measure of freezing damage has been variable, with some workers reporting unsatisfactory correlations between $\mathrm{I}_{\mathrm{t}}$ and visual assessments of damage (Zhang and Willison,

Received for publication 14 Dec. 1995. Accepted for publication 16 May 1996. H/ LA journal paper no. 94-13. This research was supported in part by the Puget Sound Seed Grower's Association, The Robert MacDonald Vegetable Seed Research Memorial Trust, and the Port of Skagit County. The cost of publishing this paper was defrayed in part by the payment of page charges. Under postal regulations, this paper therefore must be hereby marked advertisement solely to indicate this fact. ${ }^{1}$ Assistant professor. Current address: Dept. of Plant and Soil Sciences, Univ. of Massachusetts, Amherst, MA 01003-2910.

${ }^{2}$ Associate professor. To whom reprint requests should be addressed.
1987; Stergios and Howell, 1973). Murray et al. (1989) suggested that one problem with $I_{t}$ was reliance on a single measurement of conductivity after an arbitrary length of time. They concluded that the rate of electrolyte leakage, determined from a minimum of three measurements of conductivity for $5 \mathrm{~d}$, was a more reliable measure of Picea A. Dietr. shoot tissue $\mathrm{LT}_{50}$.

Whitlow et al. (1992) also questioned the reliability of $I_{t}$ when it is used to compare tissues that differ in two important factors affecting ion movement across membranes-driving force and resistance. The driving force for ion movement across the membrane is the electrochemical gradient between the cell sap and the bathing solution, a gradient determined by the ion concentration inside the tissue. Resistance to ion movement is a function of membrane surface area exposed to the bathing solution. Neglecting these variables in electrolyte leakage assays may result in erroneous conclusions when comparing the freezing tolerance of different tissues.

To account for these variables, Whitlow et al. (1992) proposed a further modification of electrolyte leakage protocol-the calculation of a coefficient of tissue ionic conductance, or $\mathrm{g}_{\mathrm{Ti}}$ :

$$
\mathrm{g}_{\mathrm{Ti}}=\mathrm{J}_{\mathrm{i}} / \mathrm{A}\left(\mathrm{c}_{\mathrm{o}}-\mathrm{c}_{\mathrm{i}}\right)
$$

where $\mathrm{J}_{\mathrm{i}}$ is the ion flux per unit time, $\mathrm{A}$ is the surface area through which diffusion occurs, and $\left(c_{o}-c_{i}\right)$ is the ion concentration gradient between the bathing solution $\left(\mathrm{c}_{\mathrm{o}}\right)$ and the tissue $\left(\mathrm{c}_{\mathrm{i}}\right)$. A complete derivation of this formula based on Fick's first law is given in Whitlow et al. (1992). Applying this formula to two separate plant systems-drought-acclimated compared with nonacclimated crab apple [Malus ioensis (A. Wood) Britt.] leaves and senescing compared with nonsenescing oak (Quercus rubra L.) leavesthey found that $\mathrm{g}_{\mathrm{Ti}}$ values were consistent with a priori expectations concerning membrane integrity, while $\mathrm{I}_{\mathrm{t}}$ values contradicted those expectations.

Although previous studies of freezing resistance in cabbage plants have focused on leaf tissue (Cox and Levitt, 1976; Kohn and Levitt, 1965; Manley and Hummel, 1996), our field observations (Manley et al., 1994) and controlled-environment freezing tests (Manley, 1994) suggested that petiole and/or stem pith freezing resistance may be the limiting factors in plant winter survival. Since samples of cabbage leaf, stem pith, and petiole tissues differ greatly in size and cut surface area, we questioned the reliability of direct comparisons of their respective freezing tolerance levels using the $\mathrm{I}_{\mathrm{t}}$ formula. While other formulas have been developed for 
interpreting electrolyte leakage data (Ingram, 1985), only the $\mathrm{g}_{\mathrm{T}}$ formula of Whitlow et al. (1992) directly accounts for differences in ion concentration and exposed surface area. In this study we compared the $\mathrm{I}_{\mathrm{t}}$ and $\mathrm{g}_{\mathrm{Ti}}$ formulas for calculating ion leakage from freeze-stressed cabbage lamina, petiole, and stem pith tissues. Our objective was to compare the two ion leakage methods of estimating tissue freeze tolerance using an assessment of tissue damage that is independent of ion leakage — vital staining with triphenyl tetrazolium chloride (TTC).

\section{Materials and Methods}

\section{Plant material}

For tissue assays, fully headed field-grown 'Golden Acre' cabbage plants were collected from a plot at the Washington State Univ. Mt. Vernon Research and Extension Unit, Mt. Vernon, Wash., on 26 Feb. and 5 Mar. 1993. Electrolyte leakage assays were conducted on the following tissues: $5 \times 8$-mm pith cylinders cut with a corkborer from the lower (just below the head), upper (within the head at the stem apex), and middle (intermediate in location) stem pith; 15-mm-diameter disks of lamina tissue cut from the apical margin of inner and outer head leaves (the February assay used only inner leaves); and 5-mm-long petiole sections cut from the bases of the same leaves. To standardize the selection of lamina and petiole tissues, the inner leaf was designated as the youngest leaf (innermost within the head) $>5 \mathrm{~cm}$ in length along the midvein axis, considered to be at insertion point one on the stem, and the outer leaf as at the tenth leaf insertion point basipetally (toward the outside of the head) from the inner leaf.

From each plant, one of each type of pith cylinder and leaf was sampled. Each leaf yielded two apical lamina disks, one from each side of the midvein, and two adjacent petiole sections. For each experiment, tissue samples were pooled by type, and individual samples of each type were randomly assigned to temperature treatments. Additional equivalent samples were used to calculate tissue surface area.

\section{Electrolyte leakage assays}

To eliminate solute leakage from cut surfaces, all tissue samples were soaked for $1 \mathrm{~h}$ in cold $\left(4^{\circ} \mathrm{C}\right)$ glass-distilled water. Then each sample was quickly blotted, weighed, and placed in a glass test tube $(20 \times 2 \mathrm{~cm})$ containing $1.5 \mathrm{~mL}$ cold $\left(4{ }^{\circ} \mathrm{C}\right)$ glass-distilled water. The capped tubes containing samples to be frozen were randomly placed in an ethylene glycol freezing bath (model 2425 $\mathrm{CH} / \mathrm{P}$; Forma Scientific, Marietta, Ohio) set at $0{ }^{\circ} \mathrm{C}$, while tubes containing nonfrozen control samples were put in a refrigerator at $4 \pm 2{ }^{\circ} \mathrm{C}$. Additional tubes containing representative tissue samples were fitted with 30-gauge copper-constantan thermocouples and randomly placed in the freezing bath. The thermocouples were then attached to a programmable datalogger (CR7X; Campbell Scientific, Inc., Logan, Utah) for constant monitoring of temperature.

The bath temperature was lowered to $-2{ }^{\circ} \mathrm{C}$ at the rate of $1{ }^{\circ} \mathrm{C} /$ h. When tissue temperature reached $-2{ }^{\circ} \mathrm{C}$, samples were nucleated with a small chip of ice (glass-distilled water) and held overnight at $-2{ }^{\circ} \mathrm{C}$ to ensure complete tissue freezing. Next, the bath temperature was lowered at a rate of $1{ }^{\circ} \mathrm{C} / \mathrm{h}$ and the samples were held at each test temperature for $1 \mathrm{~h}$ before three replicate tubes of each tissue category were removed. Tissue test temperatures of $-8,-12$, and $-16^{\circ} \mathrm{C}$ were used because the results of preliminary freezing tests indicated that these temperatures produced lamina tissue injury ranging from none to complete kill.

To ensure that ion leakage would begin at the same time for all samples, the tubes were thawed at $4 \pm 2{ }^{\circ} \mathrm{C}$ in racks surrounded by ice; thus, samples removed at $-8^{\circ} \mathrm{C}$ would not warm to above $0{ }^{\circ} \mathrm{C}$ until the $-16^{\circ} \mathrm{C}$ samples were also at that point. When all samples reached $0{ }^{\circ} \mathrm{C}$, they were quickly transferred to plastic perforated tissue capsules (Histoprep, Fisher Scientific, Pittsburgh) and submerged in a small glass bottle $(10 \times 4 \mathrm{~cm})$ containing $25 \mathrm{~mL}$ of $0.5 \%$ (by volume) Tween 20 (Sigma Chemical Co., St. Louis). Samples were then vacuum infiltrated at $0.17 \mathrm{MPa}$ for a single 30 min cycle to ensure penetration of the bathing solution into the tissues. Preliminary experiments with leaf disks indicated that $0.5 \%$ Tween 20 in the bathing solution increased the uniformity of tissue infiltration, but did not increase electrolyte leakage.

After infiltration, capsules were attached to manifold systems, each of which allowed 10 capsules to be simultaneously lifted in and out of their bathing solutions. When measurements were taken, tissue capsules were lifted out of their bathing solutions and each bottle was closed with a rubber stopper. Thus, a humid head space was maintained around the tissue sample at all times. Between measurements, while tissue capsules were submerged and the samples continuously shaken, the bottles were closed. This system allowed us to stop leakage in multiple samples at the same time, make multiple measurements of electrolyte leakage, and then resubmerge all samples at the same time without detectable damage to the tissue samples. Using this system, measurements of electrical conductivity were made at $0,15,30,60$, and $120 \mathrm{~min}$ after infiltration with an electrical conductivity meter (model CDM80; Radiometer, Copenhagen, Denmark). Since severely damaged petiole tissue had lost $>90 \%$ of electrolytes after 120 min, the measurements were halted at this point to avoid the possibility of sample fermentation (Calkins and Swanson, 1990).

After the final measurement, the tissue capsules were frozen overnight at $-75^{\circ} \mathrm{C}$ while the bathing solutions were stored at $4 \pm$ $2^{\circ} \mathrm{C}$. The capsules were then resubmerged in the bathing solutions and shaken for $2 \mathrm{~h}$ at $20 \pm 2{ }^{\circ} \mathrm{C}$ before measuring the electrical conductivity of the killed tissue samples. Finally, each sample was oven dried at $60{ }^{\circ} \mathrm{C}$ for $24 \mathrm{~h}$ and weighed.

\section{Calculations for derivation of $\mathbf{g}_{\mathrm{T}}$}

Ion concentration gradient $\left(c_{o}-c_{i}\right)$. The electrical conductivity of the bathing solution ( $\mathrm{EC}_{\mathrm{o}}$ ) at each measurement time was used as an indicator of external ion concentration where $\mathrm{c}_{\mathrm{o}}=\mathrm{EC}_{\mathrm{o}} / 25$, since the bathing solution volume was $25 \mathrm{~mL}$ (Whitlow et al., 1992). The calculation of internal ion concentration $\left(c_{i}\right)$ at each conductivity measurement time required a knowledge of the internal aqueous volume (IAV), which was determined gravi-

Table 1. Estimated mean internal ion quantity and mean surface area for ion leakage calculated for different tissues from field-grown 'Golden Acre' cabbage plants harvested on 5 Mar. 1993. Ion quantity values are based on the total conductivity of the external bathing solution after freezing the tissue at $-75^{\circ} \mathrm{C}$, divided by the internal aqueous volume. Values represent the mean of 12 replications \pm SD.

\begin{tabular}{lcc}
\hline \hline Tissue & $\begin{array}{c}\text { Estimated ion quantity } \\
\left(\mu \mathrm{S} \cdot \mathrm{mL}^{-1}\right)\end{array}$ & $\begin{array}{c}\text { Surface area } \\
\text { for ion leakage } \\
\left(\mathrm{mm}^{2}\right)\end{array}$ \\
\hline Upper pith & $472.6 \pm 124.5$ & $226.0^{2}$ \\
Middle pith & $662.0 \pm 103.5$ & 226.0 \\
Lower pith & $827.1 \pm 149.5$ & 226.0 \\
Inner leaf & $231.0 \pm 28.9$ & 43.5 \\
Outer leaf & $227.0 \pm 41.3$ & 54.5 \\
Inner petiole & $212.4 \pm 48.9$ & $73.5 \pm 9.6$ \\
Outer petiole & $222.6 \pm 55.3$ & $103.0 \pm 14.7$ \\
\hline
\end{tabular}

${ }^{\mathrm{z}}$ Pith and leaf samples were cut to uniform sizes. 
metrically by subtracting the oven-dried tissue mass from tissue fresh mass obtained after soaking and blotting (see above). Calculation of $\mathrm{c}_{\mathrm{i}}$ also required estimating the internal ion quantity at each measurement time $\left(\mathrm{EC}_{\mathrm{i}}\right)$, determined by subtracting $\mathrm{EC}_{\mathrm{o}}$ at each time from the final EC obtained after freeze-killing the tissue, a modification of the method of Whitlow et al. (1992). Therefore, $c_{i}$ $=\mathrm{EC} / \mathrm{IAV}$ for each measurement time.

Surface area for ion leakage (A). For all tissue types, the path of least resistance for ion leakage was assumed to be the cut surface (Whitlow et al., 1992). Therefore, for leaf disks and petiole sections, which had substantial intact epidermal area, calculations of A included only cut surface area. For pith cylinders, which were cut from the internal pith area of the stem, the entire surface area of the cylinder was included as A.

For purposes of determining cut surface area, leaf disks were treated as cylinders with disk volume determined by water displacement from a 10-mL pycnometer bottle (Whitlow et al., 1992). The following formula was then applied:

$$
\mathrm{T}_{\mathrm{av}}=\left(\mathrm{V} / \mathrm{A}_{\mathrm{d}}\right) / \mathrm{n} \text {, }
$$

where $\mathrm{T}_{\mathrm{av}}$ is the average disk thickness, $\mathrm{V}$ is the total volume displaced by $\mathrm{n}$ disks, and $\mathrm{A}_{\mathrm{d}}$ is the circular area of disk. For determining $\mathrm{T}_{\mathrm{av}}$, we used three replicate samples of 15 leaf disks, each $5 \mathrm{~mm}$ in diameter, cut from leaves positioned at the same insertion point on the stem as leaves used in electrolyte leakage assay. The $\mathrm{T}_{\mathrm{av}}$ was then multiplied by the circumference of the 15mm-diameter disks used in the electrolyte leakage assays to determine cut surface area.

The cut surface areas of petiole sections (two ends of each section), which varied in shape, were determined by volume displacement as described for leaf disks. Each section was considered to be a cylinder of known height $(5 \mathrm{~mm})$.

\section{Calculations for derivation of $\mathbf{I}_{\mathbf{t}}$}

The $I_{t}$ formula of Flint et al. (1967) was applied to the same data set used to calculate $\mathrm{g}_{\mathrm{Ti}}$, dividing the specific conductivity for a sample at each measurement time $\left(\mathrm{L}_{\mathrm{t}}, \mathrm{L}_{\mathrm{o}}\right)$ by the final conductivity of the sample after freeze killing $\left(\mathrm{L}_{\mathrm{k}}, \mathrm{L}_{\mathrm{d}}\right)$ to obtain a relative conductivity $\left(R_{t}, R_{o}\right)$ for each sample at each measurement time. Each value for $\mathrm{I}_{t}$ derived from these calculations was expressed as percent injury.

\section{Vital staining of tissues}

For tissues tested in March, survival of freezing treatments was also assayed using triphenyl tetrazolium chloride (TTC) (Chen et al., 1982; Steponkus and Lanphear, 1967; Takeda et al., 1993; Towhill and Mazur, 1974; Upadhyaya and Caldwell, 1993). Samples equivalent to those frozen in ion leakage assays were thawed, incubated at $4 \pm 2{ }^{\circ} \mathrm{C}$ for $48 \mathrm{~h}$ in petri dishes containing moistened filter paper, and then placed into individual glass vials containing $5 \mathrm{~mL}$ of $0.5 \%$ TTC in phosphate buffer, $\mathrm{pH} 7.3$. The samples were vacuum infiltrated for $5 \mathrm{~min}$ and left in the dark for $10 \mathrm{~h}$. Tissue samples that survived the freezing treatment without apparent injury reduced the TTC to the water-insoluble formazan and were stained red throughout the sample. Nonstained samples were considered dead. For petiole and pith tissues, the selected test temperatures, $-8,-12$, and $-16^{\circ} \mathrm{C}$, resulted in samples that either stained completely or did not stain. Thus, there was no need to further quantify tissue reduction of TTC. The TTC procedure was not effective with lamina samples.

\section{Statistical analysis}

Within each temperature treatment, analysis of variance (ANOVA) was used to test the significance of tissue differences in $\mathrm{I}_{\mathrm{t}}$ and $\mathrm{g}_{\mathrm{Ti}}$. A protected LSD was used for separating tissue means.

\section{Results}

Tissue types differed greatly in internal ion quantity and surface area for ion leakage (Table 1). The difference in internal ion quantity between the lower pith and inner petiole was 4-fold. Pith tissues also had the largest surface area for ion leakage.
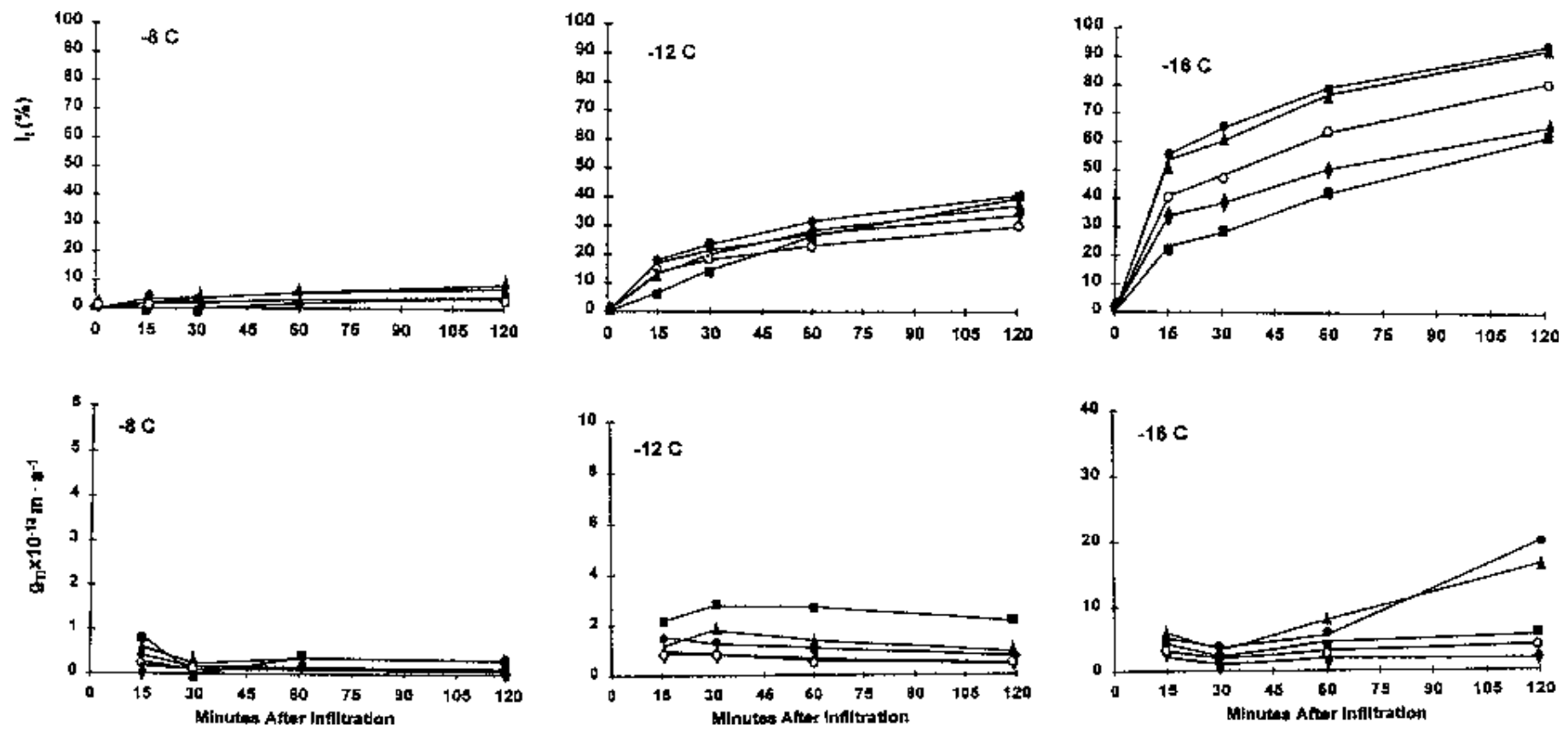

Fig. 1. Index of injury ( $\left.\mathrm{I}_{\mathrm{t}}\right)$ and tissue ionic conductance $\left(\mathrm{g}_{\mathrm{Ti}}\right)$ as a function of time for tissues from field-grown 'Golden Acre' cabbage plants collected on 26 Feb. 1993 The tissues were subjected to three levels of freezing stress, $-8,-12$, and $-16^{\circ} \mathrm{C}$. Immediately after thawing, the tissues were vacuum infiltrated for 30 min before beginning electrolyte leakage measurements at time 0 . Tissue types are indicated as follows: $\bullet$ upper pith; $\bigcirc$ middle pith; $>$ lower pith; $\boldsymbol{\square}$ inner lamina; $\boldsymbol{\Delta}$ inner petiole. Note that vertical scales vary with temperature on the $\mathrm{g}_{\mathrm{Ti}}$ graphs. 

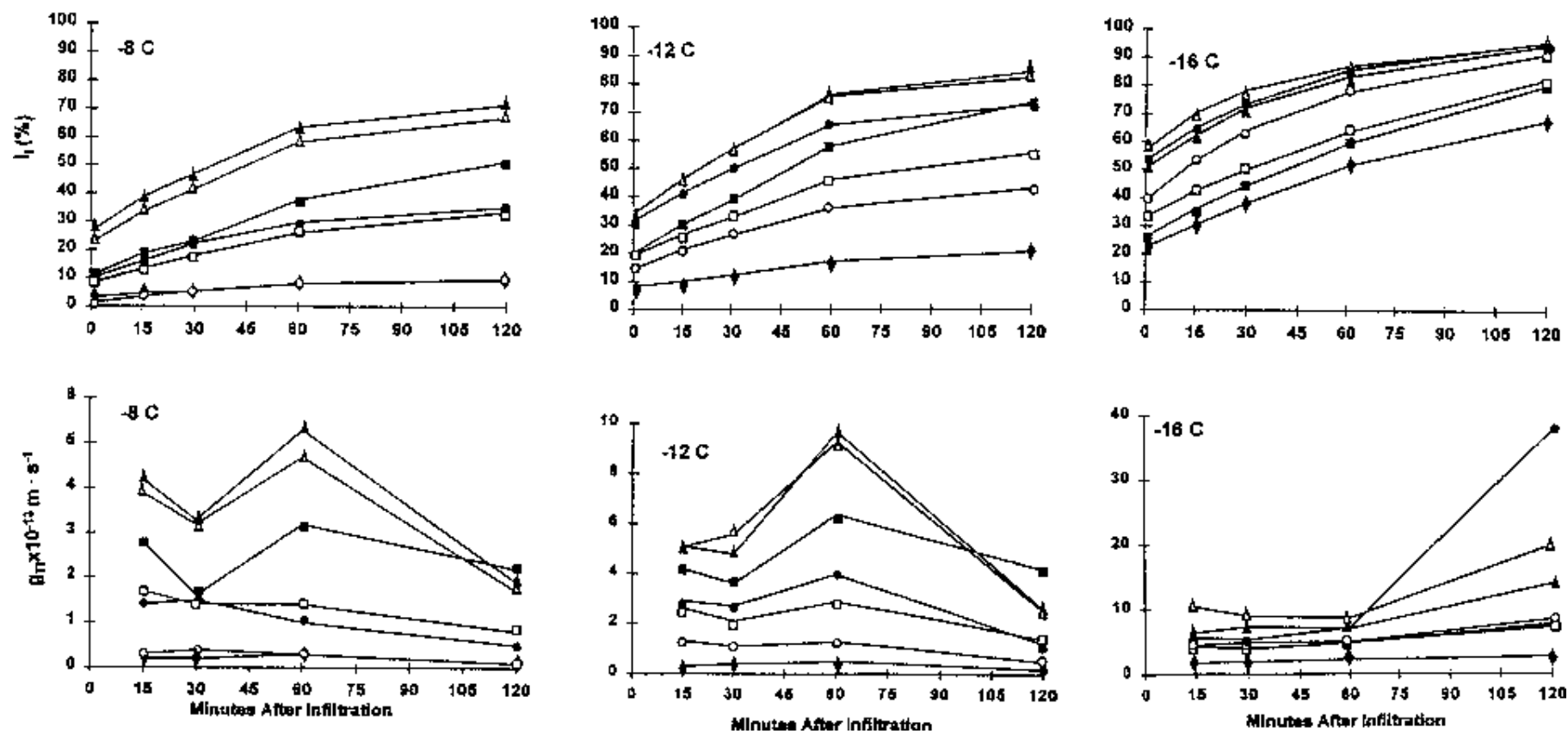

Fig. 2. Index of injury $\left(\mathrm{I}_{\mathrm{t}}\right)$ and tissue ionic conductance $\left(\mathrm{g}_{\mathrm{Ti}}\right)$ as a function of time for tissues from field-grown 'Golden Acre' cabbage plants collected on 5 Mar. 1993. The tissues were subjected to three levels of freezing stress, $-8,-12$, and $-16{ }^{\circ} \mathrm{C}$. Immediately after thawing, the tissues were vacuum infiltrated for 30 min before beginning electrolyte leakage measurements at time 0 . Tissue types are indicated as follows: $\bullet$ upper pith; $\bigcirc$ middle pith; $;$ lower pith; $\boldsymbol{\square}$ inner lamina; $\square$ outer lamina; $\boldsymbol{\Delta}$ inner petiole; $\Delta$ outer petiole. Note that vertical scales vary with temperature on the $\mathrm{g}_{\mathrm{Ti}}$ graphs.

The patterns of ion leakage in freeze-damaged tissues tested on 26 Feb. and 5 Mar. 1993 are shown in Figs. 1 and 2, respectively. A comparison of $\mathrm{I}_{\mathrm{t}}$ curves at $-8^{\circ} \mathrm{C}$ and $-12{ }^{\circ} \mathrm{C}$ for the two sample dates shows that dehardening occurred between the two dates, resulting in greater freezing injury at these temperatures to all tissues tested on 5 Mar. Vital staining of frozen pith and petiole tissues sampled on 5 Mar. clearly identified those stem pith and petiole tissues killed by freezing (Table 2). Inner and outer petiole tissues were killed at $-8^{\circ} \mathrm{C}$. All pith tissues survived $-8^{\circ} \mathrm{C}$ without injury. At $-12^{\circ} \mathrm{C}$, only the lower pith survived without injury and, at $-16^{\circ} \mathrm{C}$, all pith tissues were killed.

On 5 Mar., $\mathrm{I}_{\mathrm{t}}$ of pith tissues that survived freezing to -8 and $12{ }^{\circ} \mathrm{C}$ remained below 50\% throughout the measurement period (Fig. 2). For pith and petiole tissues that were killed by the imposed stress, $I_{t}$ had exceeded $50 \%$ by the end of the measurement period with one exception, the middle pith tissue at $-12{ }^{\circ} \mathrm{C}$.

The $\mathrm{g}_{\mathrm{Ti}} \mathrm{s}$ of nonfrozen controls were never greater than 0.2 $\times 10^{-13} \mathrm{~m} \cdot \mathrm{s}^{-1}$ for any tissue (data not shown). Stem pith and petiole tissues that were killed at -8 and $-12{ }^{\circ} \mathrm{C}$, as indicated by TTC (Table 2), showed a decrease in $\mathrm{g}_{\mathrm{Ti}}$ between 15 and $30 \mathrm{~min}$ (except the outer petiole at $-12{ }^{\circ} \mathrm{C}$ ), followed by a transient increase between 30 and $60 \mathrm{~min}$ and then a second period of reduced $\mathrm{g}_{\mathrm{Ti}}$ for the last hour (Fig. 2). When frozen to $-16{ }^{\circ} \mathrm{C}$, stem pith and petiole tissues showed steady rates of ion leakage between 15 and $60 \mathrm{~min}$, with the greatest rates of ion leakage in the last hour. Stem pith tissues that survived freezing to -8 or $-12{ }^{\circ} \mathrm{C}$ did not show the same pattern of ion leakage as freeze-killed tissues. Instead, rates of ion leakage remained low throughout the measurement period with the direction of change toward control levels.

Tables 2 and 3 compare $I_{t}$ with $g_{\text {Ti }}$ in ranking the freezing response of cabbage tissues tested in March and February 1993, respectively. Disagreement between the two formulas occurred only with lamina tissue and only when the magnitude of ion leakage was low. For example, for tissues tested in February at -8 ${ }^{\circ} \mathrm{C}$, inner lamina $\mathrm{I}_{\mathrm{t}}$ was only $1.8 \%$. The two methods of analysis did not produce the same relative freezing tolerance ranking for this

Table 2. Electrolyte leakage and triphenyl tetrazolium chloride (TTC) measurements of tissue freezing tolerance for field-grown 'Golden Acre' cabbage plants harvested on 5 Mar. 1993. Electrolyte leakage data were analyzed by two methods - index of injury $\left(\mathrm{I}_{\mathrm{t}}, \%\right)$ and tissue ionic conductance $\left(\mathrm{g}_{\mathrm{Ti}}\right.$ $\left.\times 10^{-13} \mathrm{~m} \cdot \mathrm{s}^{-1}\right)$. Each electrolyte leakage value is the mean of three replications for the 60 -min measurement time. In all TTC assays, ratings were the same for the three replicate samples.

\begin{tabular}{|c|c|c|c|c|c|c|c|c|c|}
\hline \multirow[b]{2}{*}{ Tissue $^{\mathrm{z}}$} & \multicolumn{3}{|c|}{$-8{ }^{\circ} \mathrm{C}$} & \multicolumn{3}{|c|}{$-12^{\circ} \mathrm{C}$} & \multicolumn{3}{|c|}{$-16^{\circ} \mathrm{C}$} \\
\hline & $I_{t}$ & $\mathrm{~g}_{\mathrm{Ti}}$ & TTC & $I_{t}$ & $\mathrm{~g}_{\mathrm{Ti}}$ & TTC & $I_{t}$ & $\mathrm{~g}_{\mathrm{Ti}}$ & TTC \\
\hline LPIT & $8.3 c^{y}$ & $0.3 \mathrm{c}$ & $t^{x}$ & $17.2 \mathrm{e}$ & $0.5 \mathrm{c}$ & + & $51.6 \mathrm{~d}$ & $2.2 \mathrm{~d}$ & - \\
\hline MPIT & $8.2 \mathrm{c}$ & $0.3 \mathrm{c}$ & + & $36.1 \mathrm{~d}$ & $1.3 \mathrm{c}$ & - & $77.8 \mathrm{~b}$ & $5.0 \mathrm{bc}$ & - \\
\hline UPIT & $30.0 \mathrm{~b}$ & $1.0 \mathrm{bc}$ & + & $65.4 \mathrm{ab}$ & $4.0 \mathrm{bc}$ & - & $85.5 \mathrm{a}$ & $7.1 \mathrm{a}$ & - \\
\hline ILAM & $37.9 \mathrm{~b}$ & $3.2 \mathrm{ab}$ & nt & $57.9 \mathrm{bc}$ & $6.4 \mathrm{ab}$ & nt & $59.5 \mathrm{c}$ & $4.8 \mathrm{c}$ & $\mathrm{nt}$ \\
\hline OLAM & $26.3 \mathrm{~b}$ & $1.4 \mathrm{bc}$ & $\mathrm{nt}$ & $45.9 \mathrm{~cd}$ & $2.9 \mathrm{bc}$ & $\mathrm{nt}$ & $63.6 \mathrm{c}$ & $4.8 \mathrm{c}$ & $\mathrm{nt}$ \\
\hline IPET & $63.6 \mathrm{a}$ & $5.3 \mathrm{a}$ & - & $76.2 \mathrm{a}$ & $9.7 \mathrm{a}$ & - & $83.2 \mathrm{ab}$ & $7.0 \mathrm{ab}$ & - \\
\hline OPET & $58.3 \mathrm{a}$ & $4.7 \mathrm{a}$ & - & $75.3 \mathrm{a}$ & $9.3 \mathrm{a}$ & - & 86.9 a & $8.6 \mathrm{a}$ & - \\
\hline
\end{tabular}

${ }^{\mathrm{z}}$ Lower pith (LPIT), middle pith (MPIT), upper pith (UPIT), inner lamina (ILAM), outer lamina (OLAM), inner petiole (IPET), outer petiole (OPET). yWithin columns, figures followed by the same letter are not significantly different at the $5 \%$ level using a protected LSD test.

xTTC results: $(+)$ live, $(-)$ dead, $\mathrm{nt}=$ not tested. 
Table 3. Electrolyte leakage measurements of tissue freezing tolerance for field-grown 'Golden Acre' cabbage plants harvested on 26 Feb. 1993. Electrolyte leakage data were analyzed by two methods, index of injury $\left(\mathrm{I}_{\mathrm{t}}, \%\right)$ and tissue ionic conductance $\left(\mathrm{g}_{\mathrm{Ti}} \times 10^{-13} \mathrm{~m} \cdot \mathrm{s}^{-1}\right)$. Each value is the mean of three replications for the 60 -minute measurement time.

\begin{tabular}{|c|c|c|c|c|c|c|}
\hline \multirow[b]{2}{*}{ Tissue $^{z}$} & \multicolumn{2}{|c|}{$-8^{\circ} \mathrm{C}$} & \multicolumn{2}{|c|}{$-12{ }^{\circ} \mathrm{C}$} & \multicolumn{2}{|c|}{$-16^{\circ} \mathrm{C}$} \\
\hline & $\mathrm{I}_{\mathrm{t}}$ & $\mathrm{g}_{\mathrm{Ti}}$ & $I_{t}$ & $\mathrm{~g}_{\mathrm{Ti}}$ & $I_{t}$ & $\mathrm{~g}_{\mathrm{Ti}}$ \\
\hline$\overline{\text { LPIT }}$ & $3.1 \mathrm{ab}^{\mathrm{y}}$ & $0.1 \mathrm{~b}$ & $27.2 \mathrm{a}$ & $0.7 \mathrm{~b}$ & $51.0 \mathrm{c}$ & $2.0 \mathrm{~d}$ \\
\hline MPIT & $3.1 \mathrm{ab}$ & $0.1 \mathrm{~b}$ & $23.2 \mathrm{a}$ & $0.5 \mathrm{~b}$ & $63.9 \mathrm{~b}$ & $3.1 \mathrm{~cd}$ \\
\hline UPIT & $5.5 \mathrm{a}$ & $0.2 \mathrm{~b}$ & $31.7 \mathrm{a}$ & $1.1 \mathrm{~b}$ & $79.8 \mathrm{a}$ & $5.5 \mathrm{~b}$ \\
\hline ILAM & $1.8 \mathrm{~b}$ & $0.4 \mathrm{a}$ & $26.5 \mathrm{a}$ & $2.7 \mathrm{a}$ & $42.4 \mathrm{c}$ & $4.5 \mathrm{bc}$ \\
\hline IPET & $5.8 \mathrm{a}$ & $0.4 \mathrm{a}$ & $28.4 \mathrm{a}$ & $1.4 \mathrm{~b}$ & $77.3 \mathrm{a}$ & $7.8 \mathrm{a}$ \\
\hline
\end{tabular}

${ }^{\mathrm{z}}$ Lower pith (LPIT), middle pith (MPIT), upper pith (UPIT), inner lamina (ILAM), inner petiole (IPET).

yWithin columns, figures followed by the same letter are not significantly different at the $5 \%$ level using a protected LSD test.

lamina tissue; $I_{t}$ indicated it was the least damaged of all tissue, while $\mathrm{g}_{\mathrm{Ti}}$ analysis indicated the opposite, ranking it with petiole tissue.

Both formulas agreed in ranking pith tissue tested in February at $-8{ }^{\circ} \mathrm{C}$ as more freezing tolerant than corresponding petiole tissue, with no significant differences between the three pith tissues. The $\mathrm{I}_{\mathrm{t}}$ of petiole tissue at $-8{ }^{\circ} \mathrm{C}$ was not significantly different from that of pith tissues, while the petiole $\mathrm{g}_{\mathrm{Ti}}$ was significantly greater than pith tissue. Petiole tissue had the highest ion leakage value at $-8{ }^{\circ} \mathrm{C}$ in both analyses. Freezing of tissues sampled in February to $-12{ }^{\circ} \mathrm{C}$ (Table 3 ) resulted in a range in I from $23.2 \%$ for the middle pith to $31.7 \%$ for upper pith, with no significant differences between any of the tissues. Differences in $\mathrm{g}_{\mathrm{Ti}}$ at $-12{ }^{\circ} \mathrm{C}$ for February-sampled tissues were also not statistically significant except for the $\mathrm{g}_{\mathrm{Ti}}$ of lamina tissue, which was significantly greater than all other tissues.

Of tissues tested in February at $-16{ }^{\circ} \mathrm{C}$, both formulas show petiole and upper pith tissues to be the least freezing tolerant (Table 3 ). Overall, grouping tissues tested in February at $-16^{\circ} \mathrm{C}$ according to statistically significant and nonsignificant differences, both methods of analysis would support a ranking, in order of decreasing freezing tolerance, of lower pith, lamina, middle pith, upper pith, and petiole.

In Table 2, comparing $\mathrm{I}_{\mathrm{t}}$ and $\mathrm{g}_{\mathrm{Ti}}$ for tissues tested in March, the two formulas produced essentially the same picture of tissue response to freezing stress. At all stress levels, both formulas ranked petiole tissues as having the most ion leakage, with no significant difference between inner and outer petiole tissues. Upper stem pith tissue was ranked similarly within a stress level by both formulas, as were the inner and outer lamina tissues. The upper pith tissue consistently had the greatest leakage of all pith tissues with the difference statistically significant except for $\mathrm{g}_{\mathrm{T}}$ levels at -8 and $-12{ }^{\circ} \mathrm{C}$. Both formulas showed no significant differences in ion leakage between inner and outer lamina tissues at all stress levels.

For tissues tested in March at -8 and $-12{ }^{\circ} \mathrm{C}$, both formulas ranked lower and middle stem pith tissue as having the least leakage of all tissues. At $-12^{\circ} \mathrm{C}, \mathrm{I}_{\mathrm{t}}$ ranked the lower pith as having significantly less leakage than the middle pith. Lower pith tissue was ranked by both formulas as having the least leakage of all tissues at $-16{ }^{\circ} \mathrm{C}$, as well. Middle stem pith tissue at $-16^{\circ} \mathrm{C}$ was ranked as having significantly more leakage than the lower pith by both formulas, and $\mathrm{I}_{\mathrm{t}}$ indicated the middle pith at $-16^{\circ} \mathrm{C}$ had greater leakage than both classes of lamina tissue.

\section{Discussion}

In this study, $\mathrm{I}_{\mathrm{t}}$ and $\mathrm{g}_{\mathrm{Ti}}$ produced similar rankings of cabbage tissue freezing tolerance except when the magnitude of ion leakage was low, as represented by an $\mathrm{I}_{\mathrm{t}}$ of only $1.8 \%$ for leaf lamina tissue (Table $3,-8^{\circ} \mathrm{C}$ ). Whitlow et al. (1992) also found the two formulas in opposition using experimental material with low levels of ion leakage. In their study, maximum ion leakage from droughtstressed crab apple leaves and senescing oak leaves were represented by $I_{t}$ levels of $<2 \%$ and $6 \%$, respectively. In this study, maximum ion leakage from cabbage lamina tissues was represented by an $I_{t}$ of $60 \%$ or higher.

Of the two methods of analyzing electrolyte leakage data, $I_{t}$ is much simpler and less time consuming than $\mathrm{g}_{\mathrm{T}}$. $\mathrm{I}_{\mathrm{t}}$ requires only two measurements of specific conductivity per sample and does not require weighing of tissues or determination of internal aqueous volume. The results of this study support the use of $I_{t}$ when the objective is to estimate the freezing tolerance of tissues that are subjected to severe levels of freezing stress resulting in high levels of ion leakage. The magnitude and rate of ion leakage from severely freeze-stressed cabbage tissues is apparently great enough to overcome the influence of tissue differences in ion concentration and surface area (see Table 1) that require $\mathrm{g}_{\mathrm{Ti}}$ calculations (Whitlow et al., 1992). When plant tissues respond to sublethal stress treatment with low levels of membrane leakage, $\mathrm{g}_{\mathrm{Ti}}$ analysis may be essential in obtaining an accurate picture of tissue response to stress.

Vital staining with TTC to distinguish living from dead plant tissues has been successfully used by several investigators (Chen et al., 1982; Steponkus and Lanphear, 1967; Takeda et al., 1993; Towhill and Mazur, 1974; Upadhyaya and Caldwell, 1993). In developing this procedure for cabbage tissues, stem pith and petiole tissues that were frozen to $-75^{\circ} \mathrm{C}$ were consistently unable to reduce TTC, while nonfrozen tissues always retained this ability. In the 5 Mar. freeze test, the use of 4-degree temperature intervals resulted in pith and petiole samples that were readily separated into two categories, dead or living. A smaller range of test temperatures could have resulted in the need to extract the reduced TTC from the tissue to measure treatment differences by spectrophotometry (Chen et al., 1982; Steponkus and Lanphear, 1967).

In this study, tissue viability assays using TTC support the use of $\mathrm{I}_{\mathrm{t}}$ to derive a $\mathrm{TK}_{50}$, the temperature at which $50 \%$ injury occurs, considered the tissue killing temperature. With the exception of the middle pith tissue exposed to $-12{ }^{\circ} \mathrm{C}$, pith and petiole tissues that were killed by the imposed freezing stress, as indicated by vital staining, were typically above an $\mathrm{I}_{\mathrm{t}}$ of $50 \%$, while those that survived the stress were below this point (Table 2). The $\mathrm{TK}_{50}$ provides a simple and direct means of comparison among treatments.

\section{Literature Cited}

Calkins, J.B., and B.T. Swanson. 1990. The distinction between living and dead plant tissue-Viability tests in cold hardiness research. Cryobiology 27:194-211.

Chen, H.-H., Z.-Y. Shen, and P.H. Li. 1982. Adaptability of crop plants to high temperature stress. Crop Sci. 22:719-725.

Cox, W. and J. Levitt. 1976. Interrelations between environmental factors and freezing resistance of cabbage leaves. Plant Physiol. 57:553-558.

Dexter, S.T., W.E. Tottingham, and L.F. Graber. 1930. Preliminary results in measuring the hardiness of plants. Plant Physiol. 5:215-223. Dexter, S.T., W.E. Tottingham, and L.F. Graber. 1932. Investigations of the hardiness of plants by measurement of electrical conductivity. Plant Physiol. 7:63-78. 
Flint, H.L., B.R. Boyce, and D.J. Beattie. 1967. Index of injury-A useful expression of freezing injury to plant tissues as determined by the electrolytic method. Can. J. Plant Sci. 47:229-230.

Ingram, D.L. 1985. Modeling high temperature and exposure time interactions on Pittosporum tobira root cell membrane thermostability. J. Amer. Soc. Hort. Sci. 110:470-473.

Kacperska, A. and R.K. Szaniawski. 1993. Frost resistance and water status of winter rape leaves as affected by differential shoot/root temperature. Physiol. Plant 89:775-782.

Kohn, H. and J. Levitt. 1965. Frost hardiness studies on cabbage grown under controlled conditions. Plant Physiol. 40:476-480.

Manley, R.C. 1994. The nature of freezing resistance in the stem pith of cabbage (Brassica oleracea var. capitata). PhD diss., Wash. State Univ., Pullman.

Manley, R.C. and R.L. Hummel. 1996. Mefluidide does not consistently enhance the freezing tolerance of cabbage. HortScience 31:402-404.

Manley, R.C., R.L. Hummel, and W.C. Anderson. 1994. Field observations of the winter hardiness of cabbage seed crops with plant temperature measurements during a freezing event. Proc. Western Washington Hort. Assn. 84:26-29.

Murray, M.B., J.N. Cape, and D. Fowler. 1989. Quantification of frost damage in plant tissues by rates of electrolyte leakage. New Phytol. 113:307-311.

Piotrowska, G. and A. Kacperska. 1990. Utility of leaf disks cultured in vitro for studies on frost resistance. Plant Cell Tissue Organ Cult. 22:2126.

Steponkus, P.L. and F.O. Lanphear. 1967. Refinement of the triphenyl tetrazolium chloride method of determining cold injury. Plant Physiol. 42:1423-1426.

Stergios, B.G. and G.S. Howell. 1973. Evaluation of viability tests for cold stressed plants. J. Amer. Soc. Hort. Sci. 98:325-330.

Stuart, N.W. 1939. Comparative cold hardiness of scion roots from fifty apple varieties. Proc. Amer. Soc. Hort. Sci. 37:330-334.

Takeda, F., R. Arora, M.E. Wisniewski, and G.A. Davis. 1993. Assessment of freeze injury in 'Boskoop Giant' black currant buds. HortScience 28:652-654.

Towhill, L.E. and P. Mazur. 1974. Studies on the reduction of 2,3,5triphenyl tetrazolium chloride as a viability assay for plant tissue culture. Can. J. Bot. 53:1097-1102.

Upadhyaya, A. and C.R. Caldwell. 1993. Applicability of the triphenyl tetrazolium chloride reduction viability assay to the measurement of oxidative damage to cucumber cotyledons by bisulfite. Environ. Expt. Bot. 33(3):357-365.

Whitlow, T.H., N.L. Bassuk, T.G. Ranney, and D.L. Reichert. 1992. An improved method for using electrolyte leakage to assess membrane competence in plant tissues. Plant Physiol. 98:198-205.

Zhang, M.I.N. and J.H.M. Willison. 1987. An improved conductivity method for the measurement of frost hardiness. Can. J. Bot. 65:710-715. 